\begin{tabular}{r|l|l|l}
$\begin{array}{c}\text { Case Reports in } \\
\text { Gastroenterology }\end{array}$ & $\begin{array}{l}\text { Case Rep Gastroenterol 2010;4:381-385 } \\
\text { DOl: 10.1159/000320650 }\end{array}$ & $\begin{array}{l}\text { Published online: } \\
\text { September 18, 2010 }\end{array}$ & $\begin{array}{l}\text { O 2010 S. Karger AG, Basel } \\
\text { ISSN 1662-0631 } \\
\text { www.karger.com/crg }\end{array}$ \\
\hline
\end{tabular}

\title{
A Five-Year-Old Boy with Marked Hypergastrinemia Associated with H. pylori Infection
}

\author{
Asako Nakata Hitoshi Tajiri Yuri Etani Sadami Kimura \\ Tomoko Takano
}

Department of Pediatrics, Osaka General Medical Center, Osaka, Japan

\section{Key Words}

Gastrin · Pepsinogen · Somatostatin · H. pylori · Eradication therapy · Gastrinoma

\begin{abstract}
A 5-year-old boy was referred to our department for persistent epigastric discomfort. Serum gastrin level was $635 \mathrm{pg} / \mathrm{ml}$ with a pepsinogen (PG) I level of $102.7 \mathrm{ng} / \mathrm{ml}$ and a PG I/II ratio of 23.2, indicating a hyperacidic state. Upper gastrointestinal endoscopy showed normal gastric mucosal folds and no abnormalities including no gastric mucosal atrophy. To investigate the cause of hypergastrinemia, a Ca injection test was performed and the patient showed no definitive response to a large load of $\mathrm{Ca}$. Contrast-enhanced dynamic $\mathrm{CT}$ revealed no space-occupying lesions. The results from these two studies were not consistent with the presence of gastrinoma. A urea breath test showed $2.8 \%$, and a test for the fecal $H$. pylori antigen was positive. Since H. pylori infection was considered to be a possible cause of hypergastrinemia, eradication therapy was introduced. The therapy was shown to be successful by using a repeated urea breath test that showed a normalization to $0.6 \%$. 7 months after the therapy blood examination showed a gastrin level of $191 \mathrm{pg} / \mathrm{ml}$, a PG I level of $36.7 \mathrm{ng} / \mathrm{ml}$, and a PG I/II ratio of 7.3. An immunostaining study of the gastric mucosa suggested that a decrease in somatostatin secretion due to a reduction in $D$ cell population might have induced hypergastrinemia in this case. In children with H. pylori infection showing marked hypergastrinemia, immunohistochemical examination and therapeutic diagnosis by eradication may be helpful in the differential diagnosis of gastrinoma.
\end{abstract}

\section{Introduction}

Hypergastrinemia is classified into a primary type, as observed in gastrinoma, and a secondary type mostly due to increased gastrin secretion in response to low gastric acid 


\begin{tabular}{r|l|l|l}
$\begin{array}{r}\text { Case Reports in } \\
\text { Gastruanteriology }\end{array}$ & $\begin{array}{l}\text { Case Rep Gastroenterol 2010;4:381-385 } \\
\text { DOI: 10.1159/000320650 }\end{array}$ & $\begin{array}{l}\text { Published online: } \\
\text { September 18, 2010 }\end{array}$ & $\begin{array}{l}\text { O 2010 S. Karger AG, Basel } \\
\text { ISSN 1662-0631 } \\
\text { www.karger.com/crg }\end{array}$ \\
\hline
\end{tabular}

levels. Helicobacter pylori has been described as a causative agent in some cases of hypergastrinemia. Infection can occur in early childhood, and inappropriate hypergastrinemia has been shown in asymptomatic healthy subjects with $H$. pylori infection [1]. When the pyloric antrum is infected with $H$. pylori, $\mathrm{G}$ cells can be stimulated by bacterial ammonia or by gastric mucosal cytokines produced in response to H. pylori infection. Alternatively, somatostatin production by $\mathrm{D}$ cells can be impaired by $H$. pylori infection, and a decrease in somatostatin secretion can induce increasing gastrin secretion.

We examined a young child with persistent epigastric discomfort and failure to thrive that we concluded was likely due to $H$. pylori infection. Although gastric anatomy was normal, the serum gastrin levels in the patient were markedly elevated and a differential diagnosis of gastrinoma was considered to be necessary. Based on the results of the patient's response to a Ca injection test and the clinical course after eradication treatment for $H$. pylori infection, a diagnosis of secondary hypergastrinemia associated with H. pylori infection was confirmed.

\section{Case Report}

A 5-year-old boy presented with epigastric discomfort in the summer of 2008 . The symptom was marked during fasting, especially at dawn, and relieved after meals. Neither loss of appetite nor diarrhea were noted, but there had been no weight gain during the preceding year. Due to the persistent epigastric discomfort, he was taken to an outpatient clinic and an antiemetic was started with no favorable effect. He was referred to our department for further examination. His parents and an elder sister had no history of gastric/duodenal diseases. On admission, his height was $111 \mathrm{~cm}$ and body weight was $18.3 \mathrm{~kg}$. The palpebral conjunctiva was not anemic, and epigastric tenderness was noted. The serum gastrin level was $635 \mathrm{pg} / \mathrm{ml}$, the maximum value during the course of treatment being $1,680 \mathrm{pg} / \mathrm{ml}$ (fig. 1). Serum pepsinogen (PG) I level was $102.7 \mathrm{ng} / \mathrm{ml}$ and the PG I/II ratio was 23.2, indicating a hyperacidic state. The normal values reported in children are: gastrin $92.5 \pm 39.7 \mathrm{pg} / \mathrm{ml}$, PG I $37.4 \pm$ $13.0 \mathrm{ng} / \mathrm{ml}$, and PG I/II ratio $5.8 \pm 1.6$ [2]. Upper gastrointestinal endoscopy showed normal gastric mucosal folds and no abnormalities including no gastric mucosal atrophy. Pathological examination revealed a mild degree of inflammatory cell infiltration in the gastric mucosa. Administration of an $\mathrm{H}_{2}$ blocker $(1 \mathrm{mg} / \mathrm{kg} /$ day) was started for epigastric discomfort.

To investigate the cause of hypergastrinemia, a Ca injection test was performed [3]. Ca was infused over $3 \mathrm{~h}$ at a rate of $4.0 \mathrm{mg} / \mathrm{kg} / \mathrm{h}$. In cases with gastrinoma, gastrin levels continuously increase in response to Ca injection. However, in this patient, the gastrin level did not change with Ca injection, showing no definitive response to a large load of $\mathrm{Ca}$ in $3 \mathrm{~h}$. In addition, contrast-enhanced dynamic CT revealed no space-occupying lesions. The results from these two studies were not consistent with the presence of gastrinoma. A urea breath test showed 2.8\%o (normal range $<2.5 \%$ ), and a test for the fecal $H$. pylori antigen was positive. Since $H$. pylori infection was considered to be a possible cause of hypergastrinemia, eradication therapy was performed (fig. 1). A proton pomp inhibitor (rabeprazole, $0.5 \mathrm{mg} / \mathrm{kg} /$ day), AMPC (50 mg/kg/day), and metronidazole ( $20 \mathrm{mg} / \mathrm{kg} /$ day) were administered for 14 days. The efficacy of eradication therapy was assessed after 2 months by using a repeated urea breath test that showed a normalization to $0.6 \%$. Endoscopy 5 months after therapy revealed a decrease in gastric mucosal folds while pathological examination showed a decrease in inflammatory cell infiltration. 7 months after therapy, blood examination showed a gastrin level of $191 \mathrm{pg} / \mathrm{ml}$, a PG I level of $36.7 \mathrm{ng} / \mathrm{ml}$, and a PG I/II ratio of 7.3. After the eradication, the epigastric pain gradually disappeared.

To clarify the role of somatostatin secretion in the gastric mucosa in this patient, immunostaining of the gastric mucosa with an anti-gastrin antibody and anti-somatostatin antibody was performed before eradiation therapy. G and D cells were counted at 400 -fold magnification, based on the method of Czaja et al. [4]. A gastric mucosal specimen was examined and compared to another specimen from a 7 -year-old girl who had no abnormalities detected by endoscopy or by pathological examination. The specimen from this patient showed average numbers of $78 \mathrm{G}$ cells and $24 \mathrm{D}$ cells from 3 high-power visual fields, and a G/D cell ratio of 3.25. The specimen from the control patient showed $76 \mathrm{G}$ cells, 


\begin{tabular}{r|l|l|l} 
Case Reports in & $\begin{array}{l}\text { Case Rep Gastroenterol 2010;4:381-385 } \\
\text { DOl: 10.1159/000320650 }\end{array}$ & $\begin{array}{l}\text { Published online: } \\
\text { September 18, 2010 }\end{array}$ & $\begin{array}{l}\odot \text { ISSN 1662-0631 } \\
\text { www.karger.com/crg }\end{array}$ \\
\hline
\end{tabular}

$62 \mathrm{D}$ cells, and a G/D cell ratio of 1.22. In the Czaja report, the mean G cell count was 79, D cell count 45 , and G/D cell ratio 1.79 in the normal controls [4]. The immunostaining study showed that the D cell count in this patient was lower than in controls, resulting in an increased G/D ratio.

\section{Discussion}

When food enters the stomach, gastrin is secreted by G cells in the pyloric antrum and via the circulation acts on gastrin receptors of parietal cells in the gastric body, inducing gastric juice secretion from these parietal cells. When food is propelled into the duodenum, secretin is secreted by duodenal mucosal cells and promotes somatostatin secretion by $\mathrm{D}$ cells in the gastric body. Via somatostatin, both gastrin secretion by $\mathrm{G}$ cells and gastric juice secretion by parietal cells are inhibited [5].

Hypergastrinemia is classified into a primary type, as observed in gastrinoma, and a secondary type mostly due to increased gastrin secretion in response to low gastric acid levels [1]. In this patient, because an abnormally elevated serum gastrin level with absence of gastric mucosal atrophy was noted, the possibility of gastrinoma was considered.

The diagnosis of gastrinoma is often difficult to confirm due to its small size. In addition, there are no established criteria for the diagnosis of gastrinoma, and it is made after a comprehensive evaluation based on the following examinations: serum gastrin, secretin injection test, $\mathrm{Ca}$ injection test, and angiography. Hypergastrinemia showing a serum gastrin level of more than 10 times the normal upper limit strongly suggests the presence of gastrinoma. However, $2 / 3$ of cases of gastrinoma show a gastrin level less than 10 times the normal upper limit. The secretin injection test could not be performed because secretin was not available in Japan at the time of study. The Ca injection test shows significant increases in serum gastrin level in patients with gastrinoma compared to controls. A previous study showed a positive increase in serum gastrin in $80 \%$ of patients with gastrinoma [6]. Since pancreatic endocrine tumors are generally hypervascular, angiography is also useful for their evaluation. However, its sensitivity and specificity are not high (less than $80 \%$ for each). In this patient, the gastrin level was abnormally elevated, but the presence of gastrinoma was considered to be unlikely based on the results of imaging studies and the Ca injection test.

The following hypothesis has been proposed: When the pyloric antrum is infected with H. pylori, $\mathrm{G}$ cells are stimulated by ammonia produced from the bacterium or by gastric mucosal cytokines such as IL-8 and TNF- $\alpha$ that are produced in response to H. pylori infection. Alternatively, D cell function, including somatostatin production, is impaired by $H$. pylori infection. As a result, gastrin secretion is promoted and causes hyperacidity [7]. It is also speculated that a decrease in somatostatin secretion, one of the factors inhibiting acid secretion, is the main cause of hyperacidity in H. pylori infection. A comparison of the G/D cell ratio between our study and that by Czaja et al. [4] showed no increase in $G$ cells but a decrease in $D$ cells resulting in a high G/D ratio in our patient. Thus, a decrease in somatostatin secretion due to a reduction in $\mathrm{D}$ cell population might have induced hypergastrinemia in this case.

The diagnosis of gastrinoma is generally difficult and needs a multi-faceted approach. In some cases, gastrin secretion tests using $\mathrm{Ca}$ or secretin should be performed while in other cases contrast CT should be done. In children with $H$. pylori infection showing a high gastrin level requiring differentiation from gastrinoma, immunohistological 


\begin{tabular}{r|l|l|l}
$\begin{array}{r}\text { Case Reports in } \\
\text { Gastruanteriology }\end{array}$ & $\begin{array}{l}\text { Case Rep Gastroenterol 2010;4:381-385 } \\
\text { DOI: 10.1159/000320650 }\end{array}$ & $\begin{array}{l}\text { Published online: } \\
\text { September 18, 2010 }\end{array}$ & $\begin{array}{l}\text { O 2010 S. Karger AG, Basel } \\
\text { ISSN 1662-0631 } \\
\text { www.karger.com/crg }\end{array}$ \\
\hline
\end{tabular}

examination of the gastric mucosa to identify gastrin-secreting cells and somatostatinsecreting cells to confirm a relative decrease in somatostatin production might be helpful in explaining hypergastrinemia. In addition, confirmation of a decrease in serum gastrin levels by eradication therapy in patients with $H$. pylori infection may also be feasible as a therapeutic diagnosis for excluding gastrinoma. In cases with a pending diagnosis of gastrinoma, repeated contrast-enhanced CT examination involving a high level of X-ray exposure is not desirable during childhood. In children with $H$. pylori infection showing a marked hypergastrinemia, immunohistochemical examination and therapeutic diagnosis by eradication may be helpful in the differential diagnosis of gastrinoma.

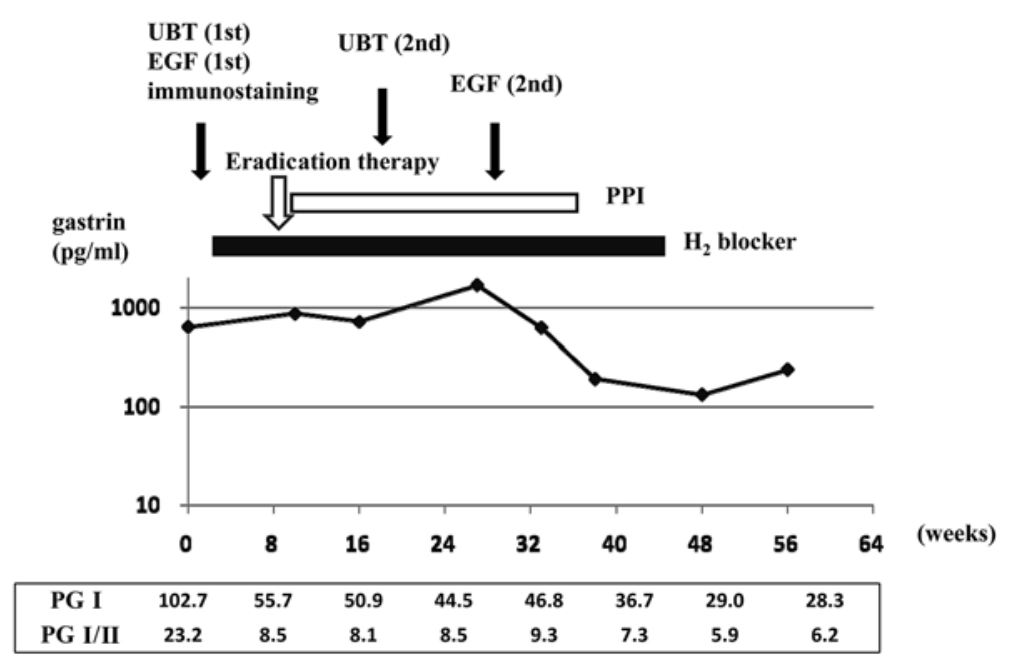

Fig. 1. The clinical course of the patient that features the changes in serum gastrin levels is shown from the time of referral to our center. The values of serum PG I levels and the PG I/II ratio that were measured at the same time of gastrin measurement are also shown in the bottom of the figure. UBT $=$ Urea breath test; $\mathrm{EGF}=$ esophagogastric fiberscopy; $\mathrm{PPI}=$ proton pomp inhibitor; $\mathrm{PG}=$ pepsinogen .

\section{References}

1 Smith JT, Pounder RE, Nwokolo CU, Lanzon-Miller S, Evans DG, Graham DY, Evans DJ Jr: Inappropriate hypergastrinaemia in asymptomatic healthy subjects infected with Helicobacter pylori. Gut 1990;31:522-525.

-2 Fukuda Y, Isomoto H, Ohnita K, Omagari K, Mizuta Y, Murase K, Murata I, Moriuchi H, Kohno S: Impact of CagA status on serum gastrin and pepsinogen I and II concentrations in Japanese children with Helicobacter pylori infection. J Int Med Res 2003;31:247-252.

-3 Wada M, Komoto I, Doi R, Imamura M: Intravenous calcium injection test is a novel complementary procedure in differential diagnosis for gastrinoma. World J Surg 2002;26:1291-1296.

-4 Czaja M, Szarszewski A, Kaminska B, Bogotko-Szarszewska M, Luczak G, Kozielska E, Delinska-Galinska A, Korzon M: Serum gastrin concentration and changes in $\mathrm{G}$ and $\mathrm{D}$ cell densities in gastric antrum in children with chronic gastritis. Int J Clin Pract 2008;62:1044-1049.

-5 Wolfe MM, Soll AH: The physiology of gastric acid secretion. N Engl J Med 1988;319:1707-1715. 
-6 Berna MJ, Hoffmann KM, Long SH, Serrano J, Gibril F, Jensen RT: Serum gastrin in Zollinger-Ellison syndrome: II. Prospective study of gastrin provocative testing in 293 patients from the National Institutes of Health and comparison with 537 cases from the literature. Evaluation of diagnostic criteria, proposal of new criteria, and correlations with clinical and tumoral features. Medicine (Baltimore) 2006;85:331-364.

7 McGee DJ, Mobley HL: Pathogenesis of Helicobacter pylori infection. Curr Opin Gastroenterol 2000;16:24-31. 